Keiko Yoshida • Tomoaki Ishigami • Ichiro Nakazawa

Akiko Ohno • Kouichi Tamura • Masahiro Fukuoka

Syunsaku Mizushima · Satoshi Umemura

\title{
Association of essential hypertension in elderly Japanese with I/D polymorphism of the angiotensin-converting enzyme $(A C E)$ gene
}

\begin{abstract}
Recent evidence suggests that an insertion/deletion (I/D) polymorphism of the gene encoding angiotensinconverting enzyme (ACE) is associated with myocardial infarction and related cardiovascular diseases. We investigated a possible association of the $A C E$ polymorphism with essential hypertension in a total of 263 cases/controls from among the elderly (age, over 70 years) and middle-aged (age between 30 and 60 years) Japanese population. The frequency of the I/I homozygote was significantly higher in hypertensive subjects than in controls in the elderly age group (33/57 vs $16 / 46 ; P=0.02)$, but no association was observed in the middle-aged group $(25 / 75$ vs $26 / 85 ; P=$ $0.71)$. Similarly, having at least one insertion allele was associated with essential hypertension in the elderly age group (83/114 vs $46 / 92$ in controls; $P=0.001)$, but not in the middle-aged group $(78 / 150$ vs $94 / 170 ; P=0.524)$. These data suggest that genetic variation at the $A C E$ locus may be associated with some determinants for blood pressure in elderly persons, and imply the involvement of the $A C E$ insertion/deletion polymorphism in the etiology of agerelated essential hypertension in the Japanese population.
\end{abstract}

Key words Angiotensin-converting enzyme · Essential hypertension · Insertion/deletion · Polymorphism · Blood pressure

K. Yoshida $\cdot$ T. Ishigami $\cdot$ I. Nakazawa $\cdot$ A. Ohno $\cdot$ K. Tamura $\cdot$

M. Fukuoka $\cdot$ S. Mizushima $\cdot$ S. Umemura

Second Department of Internal Medicine, Yokohama City

University School of Medicine, Yokohama, Japan

T. Ishigami $(\bowtie) \cdot$ I. Nakazawa

Department of Molecular Biology, Institute of Gerontology, Nippon Medical School, 1-396 Kosugi-cho, Nakahara-ku, Kawasaki 211-8503, Japan

Tel: +81-44-733-5230; Fax +81-44-733-5192

e-mail:memi@nms.ac.jp

\section{Introduction}

The renin-angiotensin system plays an important role in the regulation of blood pressure and the maintenance of vascular tone (Tamura et al. 1995). Angiotensin II, an endproduct of this system, is a vasoactive octapeptide whose effects include vasoconstriction, production of aldosterone, and enhancement of noradrenaline release from sympathetic nerve endings (Timmermans et al. 1993). Under pathological conditions, this system could influence the development and progression of cardiovascular diseases. To clarify the pathophysiological role of vasoactive substances, we and others have studied polymorphisms of several genes for potential associations with such diseases (Umemura et al. 1994; Ishigami et al. 1995a,b).

A genetic polymorphism of the human angiotensin Iconverting enzyme (ACE), which converts angiotensin I to angiotensin II, appears to be an independent risk factor for myocardial infarction (Cambien et al. 1992; Evans et al. 1994). This polymorphism occurs within intron 16 of the $A C E$ gene, in the form of the insertion or deletion (I/D) of a 287-bp Alu sequence (Rigat et al. 1992). Several cardiovascular diseases have been studied with respect to this polymorphism, which does appear to be associated with left ventricular hypertrophy (Iwai et al. 1994; Schunkert et al. 1994), with coronary atherosclerosis in smokers (Hibi et al. 1997), with hypertrophic cardiomyopathy (Marian et al. 1993), with re-stenosis after percutaneous transluminal coronary angioplasty (PTCA; Ohishi et al. 1993), and with vasospastic angina pectoris (Oike et al. 1995). In addition, increased severity of IgA nephropathy (Harden et al. 1995; Yoshida et al. 1995), chronic renal failure (Nomura et al. 1994) and carotid artery plaque (Watanabe et al. 1997) have been described in patients with a specific genotype, although such results are not consistently observed in other studies (Lindpaintner et al. 1995; Montgomery et al. 1995; Tarnow et al. 1995).

Efforts to establish an association between essential hypertension and the $A C E$ gene I/D polymorphism have been undertaken in different human populations, sometimes 
with negative results (Harrap et al. 1993; Higashimori et al. 1993; Schmidt et al. 1993; Ishigami et al. 1995a), although others have described a positive correlation (Zee et al. 1992; Morris et al. 1994). The results of some of these studies suggest that the effect of the $A C E$ polymorphism in the etiology of hypertension may vary according to whether patients are classified by sex, race, or age. In the present study, we investigated whether the I/D polymorphism of $A C E$ correlated with hypertension in age-classified groups of Japanese cases and controls.

\section{Subjects and methods}

\section{Subjects and isolation of DNA}

Adult Japanese subjects were randomly selected from among patients with essential hypertension who had been followed at the Yokohama City University Hospital, and from among persons who had come for routine health checkups (i.e., our control population). Informed consent was obtained, in the formal style approved by the Ethics Committee of the Yokohama City University Hospital, before any person was enrolled in this study. Blood samples were drawn for the extraction of genomic DNA and for the measurement of serum cholesterol, triglyceride, and highdensity lipoprotein (HDL) cholesterol.

$A C E$ genotypes were analyzed in a total of 263 subjects (132 hypertensive patients and 131 normotensive subjects). Patients were diagnosed as having essential hypertension according to the criteria of the World Health Organization, i.e., primary hypertension with systolic blood pressure (SBP) of more than $140 \mathrm{mmHg}$ and/or diastolic blood pressure (DBP) of more than $90 \mathrm{mmHg}$. Genomic DNA was extracted from these patients' peripheral blood leukocytes by standard methods, using proteinase $\mathrm{K}$ digestion of the nuclei (Sambrook et al. 1989), and was isolated by ethanol precipitation from phenolic extracts.

\section{Genotyping for the $A C E$ I/D polymorphism}

We amplified the portion of intron 16 of the $A C E$ gene that contains the polymorphic insertion/deletion by means of the polymerase chain reaction (PCR). The senseoligonucleotide primer was 5'-CTG GAC ACC ACT CCC ATC CTT TCT-3' and the antisense primer was $5^{\prime}$-GAT GTG GCC ATC ACA TTC GTC AGA T-3' (Rigat et al. 1992). Each reaction was performed in a final volume of $50 \mu \mathrm{l}$, containing $10 \mathrm{pmol}$ of each primer, $5 \mathrm{mM} \mathrm{MgCl} 2$, $50 \mathrm{mM} \mathrm{KCl}, 10 \mathrm{mM}$ Tris- $\mathrm{HCl}(\mathrm{pH} 8.4), 0.1 \mathrm{mg} / \mathrm{ml}$ gelatin, $0.5 \mu \mathrm{M}$ of each $\mathrm{dNTP}$, and 1 unit of Taq polymerase (TaKaRa, Tokyo, Japan). Because the standard method of $A C E$ genotyping (Rigat et al. 1992) may have led to missassignment of genotype, we added 5\% dimethyl sulfoxide to the reaction mixture. Amplification was carried out in a DNA Thermal Cycler (PE Biosystems, Tokyo, Japan) for 30 cycles. Each cycle included denaturation at $94^{\circ} \mathrm{C}$ for
$1 \mathrm{~min}$, annealing at $58^{\circ} \mathrm{C}$ for $1 \mathrm{~min}$, and extension at $72^{\circ} \mathrm{C}$ for $1 \mathrm{~min}$. The PCR products were electrophoresed in $1.6 \%$ agarose gels, and then visualized by ethidium bromide staining. Homozygotes for this polymorphism showed either a single 490-bp band, named I/I, or a 190-bp band (D/ D); DNA from heterozygotes (I/D) produced both bands.

\section{Statistical analyses}

The values for the data on clinical and biological characteristics of the subject groups were expressed as means \pm SE, and analyzed by Student's $t$-test. Genotypic data were sorted into categories according to the ages of patients and controls, and allelic frequencies were calculated for each group. Differences between groups were tested by $\chi^{2}$ analysis after the construction of an adequate contingency table.

\section{Results}

Background data for the hypertensive and normotensive subjects in the elderly (age, over 70 years) and middle-aged (age between 30 and 60 years) groups in our panel of 263 subjects are summarized in Table 1 . We found no significant differences between hypertensive and normotensive subjects in either age group with respect to mean age, body mass index, total cholesterol, or triglyceride concentrations.

Tables 2 and 3 show genotype frequencies (I/I, I/D, and $\mathrm{D} / \mathrm{D}$ ) and allele frequencies (I or D) for the $A C E$ polymorphism in hypertensive and normotensive elderly and middle-aged subjects, respectively. I/I homozygotes were significantly more frequent among elderly hypertensive subjects than in controls ( $33 / 57$ vs $16 / 46 ; P=0.02)$, but no association was observed in the middle-aged group (cases, 25/75 vs controls, 26/85; $P=0.71$ ).

Statistical analysis of allele frequencies indicated that the presence of at least one I allele was associated with essential hypertension in the elderly age group (83/114 vs controls, $46 / 92 ; P=0.001$; Table 2), but not in the middle-aged group (78/150 vs $94 / 170 ; P=0.524$; Table 3 ). The distribution of alleles in each age group did not deviate significantly from Hardy-Weinberg equilibrium among cases and controls.

\section{Discussion}

Animal cross-breeding studies involving stroke-prone, spontaneously hypertensive rats and Wistar-Kyoto rats have linked the $A C E$ locus to high blood pressure (Hilbert et al. 1991; Jacob et al. 1991). Association studies between essential hypertension and the $A C E$ gene I/D polymorphism have also been performed in various human populations. Some research groups have failed to observe any correlation (Harrap et al. 1993; Higashimori et al. 1993; Schmidt et al. 1993; Ishigami et al. 1995a), but others have reported significant correlation (Zee et al. 1992; Morris et 
Table 1. Clinical characteristics of patients with hypertension (HT) and normotensive (NT) controls in each age group

\begin{tabular}{|c|c|c|c|c|}
\hline & \multicolumn{2}{|c|}{ Middle-aged $(30<$ age $<60$ years $)$} & \multicolumn{2}{|c|}{ Elderly (age, $>70$ years) } \\
\hline & HT & NT & HT & NT \\
\hline Number of subjects & 75 & 85 & 57 & 46 \\
\hline Age (years) & $50.5 \pm 0.8$ & $49.7 \pm 0.7$ & $75.8 \pm 0.7$ & $76.5 \pm 0.9$ \\
\hline T. Chol (mg/dl) & $209.0 \pm 5.3$ & $211.6 \pm 7.0$ & $201.9 \pm 5.2$ & $197.7 \pm 7.2$ \\
\hline $\mathrm{TG}(\mathrm{mg} / \mathrm{dl})$ & $150.1 \pm 7.0$ & $140.1 \pm 10.2$ & $118.0 \pm 7.5$ & $126.8 \pm 11.6$ \\
\hline HDL-C (mg/dl) & $48.1 \pm 5.7$ & $47.8 \pm 2.4$ & $48.2 \pm 2.4$ & $43.4 \pm 2.3$ \\
\hline BMI $\left(\mathrm{kg} / \mathrm{m}^{2}\right)$ & $24.5 \pm 0.4$ & $23.1 \pm 0.3$ & $21.9 \pm 0.4$ & $21.1 \pm 0.9$ \\
\hline No. of DM patients & $31 / 75$ & $25 / 85$ & $15 / 57$ & $13 / 46$ \\
\hline Male/Female & $42 / 33$ & $57 / 28$ & $30 / 27$ & $25 / 21$ \\
\hline Age at onset of HT & $42.6 \pm 1.5$ & - & $56.2 \pm 3.2$ & - \\
\hline Family history $(+)$ & $53 / 75$ & $20 / 85$ & $32 / 57$ & $8 / 46$ \\
\hline
\end{tabular}

Data values are expressed as numbers of subjects, and means \pm SE

T. Chol., Total cholesterol concentration; TG, triglyceride concentration; HDL-C, high-density lipoprotein cholesterol concentration; BMI, body mass index; DM, diabetes mellitus

Table 2. Frequencies of genotypes and alleles for the $A C E \mathrm{I} / \mathrm{D}$ polymorphism in elderly (age, $>70$ years) hypertensives (HT) and normotensives (NT) in the Japanese population

\begin{tabular}{|c|c|c|c|c|c|c|c|c|}
\hline \multicolumn{5}{|c|}{ Genotype $(n)$} & \multicolumn{4}{|c|}{ Allele frequencies } \\
\hline & $\mathrm{I} / \mathrm{I}^{*}$ & $\mathrm{I} / \mathrm{D}$ & $\mathrm{D} / \mathrm{D}$ & Total & & I & $\mathrm{D}$ & Total \\
\hline HT & 33 & 17 & 7 & 57 & HT & $83(0.73)$ & $31(0.27)$ & 114 \\
\hline \multirow[t]{2}{*}{ NT } & 16 & 14 & 16 & 46 & NT & $46(0.50)$ & $46(0.50)$ & 92 \\
\hline & & & & 103 & & & & 206 \\
\hline
\end{tabular}

$A C E$, Angiotension-converting enzyme gene; I, insertion; $\mathrm{D}$, deletion

al. 1994). Some previous studies (Zee et al. 1992; Morris et al. 1994) described a positive association of hypertension with the $A C E$ gene $\mathrm{D}$ allele, rather than the I allele that was associated with hypertension in the present study. Such a discrepancy could result from various factors, as follows. The allele distribution of polymorphisms may be different in different countries or even in different areas of the same country. Indeed, the allele distribution of the normotensives listed in Table 2, who were collected in the Yokohama area of Japan, is different from that reported in previous studies, as mentioned above. In addition, because our study sample size was relatively small, the remote possibility of a false-positive result can not be ruled out.

Observations of genetic linkage, as well as association between the $A C E$ locus and blood pressure, tend to be stronger when the study population is restricted to men, as in the Framingham Heart Study, in which diastolic pressure was associated with $\mathrm{D}$ genotype in men (O'Donnell et al. 1998), or to young Caucasian men (Fornage et al. 1998). In addition, Turner et al. (1999) reported that an $A C E$ I/D polymorphism was associated with blood pressure in a sexand age-dependent manner. Furthermore, ethnic differences in the frequencies of the $\mathrm{I}$ and $\mathrm{D}$ alleles of the $A C E$ gene (Barley et al. 1994; Lee 1994; Ishigami et al. 1995a,b) and in the serum activity of this enzyme have complicated the comparison of data among different population samples (Bloem et al. 1996). In the present study, we investigated the $A C E \mathrm{I} / \mathrm{D}$ polymorphism for correlation with essential
Table 3. Frequencies of genotypes and alleles for the $A C E \mathrm{I} / \mathrm{D}$ polymorphism in middle-aged (age, $<60$ years) hypertensives (HT) and normotensives (NT) in the Japanese population

\begin{tabular}{|c|c|c|c|c|c|c|c|c|}
\hline \multicolumn{5}{|c|}{ Genotype $(n)$} & \multicolumn{4}{|c|}{ Allele frequencies } \\
\hline & $\mathrm{I} / \mathrm{I}^{*}$ & $\mathrm{I} / \mathrm{D}$ & $\mathrm{D} / \mathrm{D}$ & Total & & I & $\mathrm{D}$ & Total \\
\hline HT & 25 & 28 & 22 & 75 & HT & $78(0.52)$ & $72(0.48)$ & 150 \\
\hline NT & 26 & 42 & 17 & $\begin{array}{r}85 \\
160\end{array}$ & NT & $94(0.55)$ & $76(0.45)$ & $\begin{array}{l}170 \\
320\end{array}$ \\
\hline
\end{tabular}

(NS)

hypertension in age-classified groups of Japanese cases and controls. Morris et al. (1994) had observed that the D/D genotype at the $A C E$ locus was less common in elderly hypertensive Caucasian patients than in age-matched controls. We have demonstrated here an association between increased frequency of the $A C E$ insertion allele in older Japanese patients with essential hypertension, but not in the younger Japanese patients. Our data accord, in general, with the observations of Morris et al. (1994), although the frequencies of the genotypes and alleles were quite different in the Japanese and Caucasian test populations. The results reported here support an idea suggested by O'Donnell et al. (1998), Fornage et al. (1998), and Turner et al. (1999), that the role of $A C E$ gene variation in the etiology of essential hypertension may differ according to the type of disease and/or the sex, race, or age of the patients.

Previous studies have suggested that the D allele of the $A C E$ gene was associated with several cardiovascular diseases, such as left ventricular hypertrophy (Iwai et al. 1994; Schunkert et al. 1994), coronary atherosclerosis in smokers (Hibi et al. 1997), hypertrophic cardiomyopathy (Marian et al. 1993), re-stenosis after percutaneous transluminal coronary angioplasty (PTCA; Ohishi et al. 1993), and vasospastic angina pectoris (Oike et al. 1995). Increased plasma activity of the ACE enzyme correlates with thickening of the wall of the carotid artery (Bonithon-Knopp et al. 1994). In addition, Danser et al. (1995) reported higher levels of atrial $A C E$ mRNA in humans with the $\mathrm{D} / \mathrm{D}$ genotype than 
in subjects with other genotypes. Another report suggested that renin-angiotensin activity in rat plasma declined with age (Costerousse et al. 1994). Also, in rat models, mRNA levels of both angiotensinogen and $A C E$ increased in the left ventricle during senescence, while the activity of the renin-angiotensin system decreased in the plasma (Heymes et al. 1994). Local activation of the renin-angiotensin system may induce remodeling of the vasculature, which could lead to a variety of cardiovascular and other consequences.

The present study indicates that age should be considered in the evaluation of data concerning $A C E$ genotypes, especially for patients with essential hypertension. In this connection, it is intriguing to note an association between the DD genotype and longevity described by Schachter et al. (1994). Those investigators suggested that the association with longevity may indicate the presence of mechanisms such as improvement in the repair of damaged tissues, or increased resistance to neoplasia and infection (Costerousse et al. 1993; Luft 1999). One might also find beneficial effects on neurons in aged subjects in relation to genetic variations at the $A C E$ locus. In light of these ideas, it would be intriguing to determine $A C E$ genotypes in Japanese centenarians.

In conclusion, we suggest that certain genetic variations at the $A C E$ locus may be associated with some determinants for blood pressure in the elderly, and that the insertion/deletion polymorphism may be involved in the etiology of essential hypertension in this age group in Japan.

Acknowledgments This work was supported in part by grants from the Ministry of Education, Science, and Culture of Japan (nos. 08258222, 08407020, 02670404, 05670956, and 09770492) and by a grant from the Uehara Memorial Foundation.

\section{References}

Barley J, Blackwood A, Carter ND, Crews DE, Cruickshank JK, Jeffery S, Ogunlesi AO, Sagnella GA (1994) Angiotensin-converting enzyme insertion/deletion polymorphism: association with ethnic origin. Hypertension 12:955-957

Bloem LJ, Manatunga AK, Pratt JH (1996) Racial difference in the relationship of an angiotensin I-converting enzyme gene polymorphism to serum angiotensin I-converting enzyme activity. Hypertension 27:62-66

Bonithon-Knopp C, Ducimetiere P, Touboul PJ, Feve JM, Billaud E, Courbon D, Heraud V (1994) Plasma angiotensin converting enzyme activity and carotid wall thickening. Circulation 89:952-954

Cambien F, Poirier O, Lecerf L, Evans A, Cambou JP, Arveiler D, Luc G, Bard JM, Bara L, Ricard S (1992) Deletion polymorphism in the gene for angiotensin-converting enzyme is a potent risk factor for myocardial infarction. Nature 359:641-644

Costerousse O, Jaspard E, Alhenc-Gelas F (1993) Molecular and genetic aspects of dipeptidyl carboxypeptidase-1 (the angiotensin-I converting enzyme) expression in the immune system. Adv Neuroimmunol 3:217-226

Costerousse $\mathrm{O}$, Allegrini J, Huang $\mathrm{H}$, Bounhik J, Alhenc-Gelas $\mathrm{F}$ (1994) Regulation of $A C E$ gene expression and plasma levels during rat postnatal development. Am J Physiol 265:745-753

Danser AHJ, Schalekamp MADH, Bax WA, van den Brink AM, Saxena PR, Riegger GA, Schunkert H (1995) Angiotensinconverting enzyme in the human heart: effect of the deletion/ insertion polymorphism. Circulation 92:1387-1388

Evans AE, Poirier O, Kee F, Lecerf L, McCrum E, Falconer T, Crane J, O'Rourke DF, Cambien F (1994) Polymorphism of the angiotensin-converting-enzyme gene in subjects who die from coronary heart disease. Q J Med 87:211-214

Fornage M, Amos CI, Kardia S, Sing CF, Turner ST, Boerwinkle E (1998) Variation in the region of the angiotensin-converting enzyme gene influences interindiviudual differences in blood pressure levels in young white males. Circulation 97:1773-1779

Harden PN, Geddes C, Rowe PA, McIlroy JH, Boulton-Jones M, Rodger RS, Junor BJ, Briggs JD, Connell JM, Jardine AG (1995) Polymorphism in angiotensin-converting-enzyme gene and progression of IgA nephropathy. Lancet 345:1540-1542

Harrap SB, Davidson R, Connor M, Soubrier F, Corvol P, Faster R, Foy CJ, Watt GC (1993) The angiotensin I converting enzyme gene and predisposition to high blood pressure. Hypertension 21:455-460

Heymes C, Swynghedauw B, Chevalier B (1994) Activation of angiotensinogen and angiotensin-converting enzyme gene expression in the left ventricle of senescent rats. Circulation 90:13281333

Hibi K, Ishigami T, Kimura K, Nakao M, Iwamoto T, Tamrua K, Nemoto T, Shimizu T, Mochida Y, Ochiai H, Umemura S, Ishii M (1997) Angiotensin converting enzyme gene polymorphism adds risk for the severity of coronary atherosclerosis in smokers. Hypertension 30:574-579

Higashimori K, Zhao Yi, Higaki J, Kamitani A, Katsuya T, Nakura J, Miki T, Mikami H, Ogihara T (1993) Association analysis of a polymorphism of the angiotensin converting enzyme gene with essential hypertension in the Japanese population. Biochem Biophys Res Commun 191:399-404

Hilbert P, Lindpaintner K, Beckmann JS, Serikawa T, Soubrier F, Dubay C, Cartwright P, De Gouyon B, Julier C, Takahasi S (1991) Chromosomal mapping of two genetic loci associated with bloodpressure regulation in hereditary hypertensive rats. Nature 353:521529

Ishigami T, Iwamoto T, Tamura K, Yamaguchi S, Iwasawa K, Uchino K, Umemura S, Ishii M (1995a) Angiotensin I-converting enzyme gene polymorphism and essential hypertension in Japan. Am J Hypertens 8:95-97

Ishigami T, Umemura S, Iwamoto T, Tamura K, Hibi K, Yamaguchi S, Nyuui N, Kimura K, Miyazaki N, Ishii M (1995b) Molecular variant of angiotensinogen gene is associated with coronary atherosclerosis. Circulation 91:951-954

Iwai N, Ohmichi N, Nakamura Y, Kinoshita M (1994) DD genotype of the angiotensin-converting enzyme gene is a risk factor for left ventricular hypertrophy. Circulation 90:2622-2628

Jacob HJ, Lindpaintner K, Lincoln SE, Kusumi K, Bunker RK, Mao YP, Ganten D, Dzau VJ, Lander ES (1991) Genetic mapping of a gene causing hypertension in the stroke-prone spontaneously hypertensive rat. Cell 67:213-214

Lee EJD (1994) Population genetics of the angiotensin converting enzyme in Chinese. Br J Clin Pharmacol 37:212-214

Lindpaintner K, Pfeffer MA, Kreutz R, Stampfer MJ, Grodstein F, LaMotte F, Buring J, Hennekens CH (1995) A prospective evaluation of an angiotensin-converting enzyme gene polymorphism and the risk of ischemic heart disease. N Engl J Med 332:706-711

Luft FC (1999) Bad genes, good people, association, linkage, longevity and the prevention of cardiovascular disease. Clin Exp Pharmacol Physiol 7:576-579

Marian A, Yu Q, Workman R, Greve G, Roberts R (1993) Angiotensin-converting enzyme polymorphism in hypertrophic cardiomyopathy and sudden cardiac death. Lancet 342:1085-1086

Montgomery HE, Keeling PJ, Goldman JH, Humphries SE, Talmud PJ, McKenna WJ (1995) Lack of association between the insertion/ deletion polymorphism of the angiotensin-converting enzyme gene and idiopathic dilated cardiomyopathy. J Am Coll Cardiol 25:16271631

Morris BJ, Zee YL, Schrader AP (1994) Different frequencies of angiotensin-converting enzyme genotypes in older hypertensive individuals. J Clin Invest 94:1085-1089

Nomura H, Koni I, Michishita Y, Morise T, Takeda R (1994) Angiotensin-converting enzyme gene polymorphism in haemodialysis patients. Lancet 343:482-448

O'Donnell CJ, Lindpaintner K, Larson MG, Rao VS, Ordovas JM, Schaefer EJ, Myers RH, Levy D (1998) Evidence for association and genetic linkage of the angiotensin-converting enzyme locus with hypertension and blood pressure in men but not women in the Framingham Heart Study. Circulation 18:1766-1772 
Ohishi M, Fujii K, Minamino T, Higaki J, Kamitani A, Rakugi H, Zhao Y, Mikami H, Miki T, Ogihara T (1993) A potent genetic risk factor for restenos. Nat Genet 5:324-325

Oike Y, Hata A, Ogata Y, Numata Y, Shido Y, Kondo K (1995) Angiotensin-converting enzyme as a genetic risk factor for coronary artery spasm. J Clin Invest 96:2975-2979

Rigat B, Hubert C, Corvol P, Soubrier F (1992) PCR detection of the insertion/deletion polymorphism of the human angiotensinconverting enzyme gene. Nucleic Acids Res 20:1433

Sambrook J, Fritsch EF, Maniatis T (1989) Molecular cloning: a laboratory manual. Cold Spring Harbor Laboratory Press, New York, pp 9.16-9.19

Schachter F, Faure-Delanef L, Guenot F, Rouger H, Froguel P, Lesueur-Ginot L, Cohen D (1994) Genetic associations with human longevity at the APOE and ACE loci. Nat Genet 6:29-32

Schmidt S, von Hooft IMS, Grobbee DE, Ganten D, Ritz E (1993) Polymorphism of the angiotensin I-converting enzyme gene is apparently not related to high blood pressure: Dutch hypertension and offspring study. J Hypertens 11:345-348

Schunkert H, Hense HW, Holmer SR, Stender M, Perz S, Keil U, Lorell BH, Riegger GA (1994) Association between a deletion polymorphism of the angiotensin-converting-enzyme gene and left ventricular hypertrophy. New Engl J Med 330:1634-1638

Tamura K, Umemura S, Fukamizu A, Ishii M, Murakami K (1995) Recent advances in the study of renin and angiotensinogen genes from molecules to the whole body. Hypertension Res 18:7-18

Tarnow L, Cambien F, Rossing P, Nielsen FS, Hansen BV, Lecerf L, Poirier O, Danilov S, Parving HH (1995) Lack of relationship between an insertion/deletion polymorphism in the angiotensin Iconverting enzyme gene and diabetic nephropathy and proliferative retinopathy in IDDM patients. Diabetes 44:489-494

Timmermans PBMWM, Wong PC, Chiu AT, Herblin WF, Benfield P, Carini DJ, Lee RJ, Wexler RR, Saye JA, Smith RD (1993) Angiotensin II receptors and angiotensin II receptor antagonists. Pharmacol Rev 45:205-225

Turner St, Boerwinkle E, Sing CF (1999) Context-dependent associations of the ACE I/D polymorphism with blood pressure. Hypertension 34:773-778

Umemura S, Hirawa N, Iwamoto T, Yamaguchi S, Toya Y, Kobayashi S, Takasaki I, Yasuda G, Tamura K, Ishii M (1994) Association analysis of restriction fragment length polymorphism for alpha2adrenergic receptor genes in essential hypertension in Japan. Hypertension 23:1203-1206

Watanabe $\mathrm{Y}$, Ishigami $\mathrm{T}$, Kawano $\mathrm{Y}$, Umahara $\mathrm{T}$, Nakamori A, Mizushima S, Hibi K, Kobayashi I, Tamura K, Ochiai H, Umemura S, Ishii M (1997) Angiotensin-converting enzyme gene I/D polymorphism and carotid plaques in Japanese. Hypertension 30:569573

Yoshida H, Mitarai T, Kawamura T, Kitajima T, Miyazaki Y, Nagasawa R, Kawaguchi Y, Kubo H, Ichikawa I, Sakai O (1995) Role of the deletion polymorphism of the angiotensin-converting enzyme gene in the progression and therapeutic responsiveness of IgA nephropathy. J Clin Invest 96:2162-2169

Zee RYL, Lou YK, Griffiths LR, Morris BJ (1992) Association of a polymorphism of the angiotensin I-converting enzyme gene with essential hypertension. Biochem Biolphys Res Commun 184:9-15 